\title{
SISTEM PENCARIAN HOTEL BERDASARKAN RUTE PERJALANAN TERPENDEK DENGAN MEMPERTIMBANGKAN DAYA TARIK WISATA MENGGUNAKAN ALGORITMA GREEDY
}

\author{
Audrey Maximillian Herli ${ }^{1)}$ Indra Kharisma Raharjana ${ }^{2)}$, Purbandini $^{3)}$ \\ Program Studi Sistem Informasi, Fakultas Sains dan Teknologi, Universitas Airlangga \\ Kampus C Mulyorejo, Surabaya \\ 1)audreymaxi-11@fst.unair.ac.id, \\ ${ }^{2)}$ indra.kharisma@fst.unair.ac.id \\ ${ }^{3)}$ purbandini@fst.unair.ac.id
}

\begin{abstract}
Abstrak- Pencarian hotel merupakan hal yang penting dilakukan wisatawan dalam melakukan perjalanan wisata. Wisatawan akan mempertimbangkan kriteria hotel seperti kelas, harga dan review hotel. Selain itu faktor jarak hotel dan tempat wisata yang dikunjunginya adalah hal yang penting untuk dipertimbangkan. Pada penelitian ini dibangun sistem untuk melakukan pencarian hotel berdasarkan rute perjalanan wisata terpendek dengan daya tarik wisata mengunakanalgoritma greedy untuk memudahkan wisatawan dalam melakukan efisensi jarak perjalanan wisata serta membantu dalam pemilihan hotel. Penelitian ini dilakukan melalui empat tahap, tahap pertama adalah pengumpulan data dan informasi daya tarik wisata dan hotel. Tahap kedua adalah analisa data dengan algoritma greedy serta melakukan penyesuian pengunaan algoritma berdasarkan karakteristik perjalanan yang dilakukan wisatawan. Tahap ketiga adalah pembangunan sistem, dan tahap terakhir adalah melakukanevaluasi sistem bersama para ahli yang telah berpengalaman dalam bidang pariwisata dan calon penguna aplikasi ini.Hasil dari penelitian ini adalah sistem yang dapat memberikan rekomendasi rute dan urutan perjalanan terpendek antara hotel dan daya tarik wisata berdasarkan algoritma greedy.
\end{abstract}

Kata Kunci- Hotel, Daya Tarik Wisata, Algoritma Greedy, Rute Perjalanan Terpendek

Abstract - Hotel search was an important thingfor travelers in their traveling journey. Travelers would consider criteria such as class, price and review of the hotel.Beside those things, distance between Hotel and tourist attractionswasalsoimportant factor to be considered. In this research, system was constructed to perform a hotels search by shortest travelling route using Greedy Algorithm. This research was conducted through four stages, the first stage wasdata and information collectingof tourist attraction and hotel. Second stagewasdata analysis with greedy algorithm in purpose to classify the data and implementing greedy algorithm with manual calculation to the problem research. The third stage was the development of the system, and the last stage wasevaluating the system with the experts who are experienced in the field of tourism and the prospective user of this application. Results from this study was the system can provide recommendations and sequence the shortest journey between the hotel and tourist attraction based on the greedy algorithm.

Keywords- Hotel, Tourist Attraction, Greedy Algorithm, Travelling Salesman Problem

\section{PENDAHULUAN}

Indonesia dengan 34 provinsi dan lebih dari 13000 pulau Indonesia memiliki berbagai macam kekayaan alam serta budaya dan beragam sehingga Indonesia juga menjadi tujuan pariwisata dengan daya tarik wisata yang sangat menarik yang tersebar di berbagai daerah. Dengan adanya banyak daya tarik wisata di Indonesia, hal ini juga diikuti oleh bertambahnya jumlah hotel sebagai tempat singgah para wisatawan.Dari fenomena ini, banyaknya pilihan daya tarik wisata dan hotel seringkali menimbulkan permasalahan bagi para wisatawan yaitu dalam mencari atau menentukan hotel berdasarkan rute perjalanan terdekat dengan daya tarik wisata yang beraneka ragam tersebut.
Pencarian hotel membuat pengunjung perlu menentukan hotel yang tepat dengan membuat sistem yang dapat memberikan rekomendasi hotel sesuai dengan kriterianya(Fariza, Setyowati, \& Putra, 2012). Salah satu kriteria pemilihan hotel yang penting adalah jarak menuju lokasi hotel (Pristanto, Wahyuni, \& Handini, 2012)sehingga faktor jarak dari penelitian ini dapat diketahui bahwa jarak merupakan hal yang dipertimbangkan oleh pengunjung sehingga dalam penelitian yang akan dilakukan jarak akan digunakan sebagai elemen utama dalam menentukan pencarian hotel.Hal ini pertimbangan untuk mengangkat permasalahan pencarian hotel berdasarkan rute perjalanan terpendek dengan daya tarik wisata karena merupakan masalah yang penting dan 
menarik untuk diselesaikan mengingat potensi Jawa Timur sebagai daya tarik wisata yang terus berkembang.

Solusi yang dapat menyelesaikan permasalahan ini adalah dengan membangun suatu sistem yang dapat melakukan pencarian hotel yang memiliki rute perjalanan terpendek dengan daya tarik wisata yang akan dikunjungi. Para calon wisatawan dapat memilih daya tarik wisata yang akan dikunjungi melalui sistem kemudian sistem akan memberikan daftar hotel beserta rute perjalanan terpendek dengan daya tarik wisata yang dipilihnya dan calon wisatawan juga dapat menentukan rute dari current location mereka.

Manfaat dari dilaksanakan penelitian ini adalah agar memudahkan pencarian hotel dan urutan perjalanan wisata berdasarkan rute perjalanan terpendek dengan daya tarik wisata bagi para wisatawan yang menggunakan sistem ini

Solusi yang ditawarkan akan diwujudkan menggunakan Algoritma Greedy. Algoritma Greedy merupakan algoritma yang membentuk solusi langkah per langkah. Pada setiap langkah tersebut akan dipilih keputusan yang paling optimal.Algoritma ini adalah salah satu penyelesaian Travelling Salesman Problem (TSP), TSP adalah permasalahan untuk mencari rute perjalanan terpendek setelah mengunjungi semua titik lokasi sehingga hal ini dapat diterapkan pada penelitian, wisatawan dapat mencari hotel dengan rute perjalanan terpendek setelah mengunjungi seluruh titik daya tarik wisata secara optimal.

Mengingat para pengguna sistem adalah para wisatawan yang selalu berpindah-pindah tempat dalam melakukan perjalanan wisata maka sistem akan dibangun dengan Android mobile platform.Android menyediakan platform terbuka bagi para pengembang untuk menciptakan aplikasi (Nazruddin, 2012).

Sistem juga akan diintegerasikan dengan Google Map untuk penentuan lokasi hotel, daya tarik wisata, rute dan navigasi peta digital. Studi kasus dalam penelitian ini akan menggunakan daya tarik wisata dan hotel yang ada di wilayah Jawa Timur.

\section{TINJAUAN PUSTAKA}

Algoritma Greedy memiliki pendekatan untuk membangun solusi secara bertahap melalu urutan yang terus berkembang sampai solusi dari masalah telah tercapai (Levitin \& Mukherjee, 2007). Greedy memberikan alternatif optimal lokal dengan harapan setiap alternatif lokal menghasilkan alternatif global yang optimal secara keseluruhan.Algoritma Greedy dapat menyelesaikan Travelling Salesman Problem dengan menghitung nilai lokal optimal setiap mengunjungi kota dan mendapatkan nilai optimasi global pada akhir perjalanan.(Lukman, AR, \& Nurhayati, 2011)
Algoritma Greedy dalam penelitian terdahulu dapat diimplementasikan dalam melakukan optimasi jarak seperti dalam menentukan jarak terdekat atau shortest path dan Travelling Salesman Problem (TSP).TSPmerupakan representasi masalah dalam penelitian ini yaitu menentukan rute perjalanan terpendek antara hotel dengan daya tarik wisata setelah mengunjungi seluruhnya.

Algoritma Greedy dapat menentukan jalur mana yang akan diambil terlebih dahulu atau dapat disebut dengan jalur optimum lokal sehingga sampai seluruh jalur diambil pada akhir perjalanan dan menciptakan rute perjalanan terpendek atau disebut dengan optimum global sehingga dapat pula menyelesaikan TSP. Dari sini dapat ditentukan nilai rute perjalanan terpendek antara hotel dengan daya tarik wisata.

Persoalan optimasi dalam konteks Algoritma Greedy disusun oleh komponen-komponen sebagai berikut (Efendi, Pinto, \& Tempake, 2012) :

a) Himpunan Kandidat (C) : Merupakan himpunan yang berisi elemen-elemen pembentuk solusi. Pada setiap langkah, satu buah kandidat diambil dari himpunannya.

b) Himpunan Kandidat, (C) : Himpunan Kandidat merupakan himpunan yang berisi mengenai elemen pembentuk Solusi.

c) Himpunan Solusi, (S): Himpunan Solusi merupakan himpunan-himpunan yang berisi elemen solusi pemecahan masalah.

d) Fungsi Seleksi : Fungsi Seleksi adalah fungsi yang pada setiap langkah memilih kandidat yang paling memungkinkan mencapai solusi optimal. Kandidat yang sudah dipilih pada suatu langkah tidak pernah dipertimbangkan lagi pada langkah selanjutnya.

e) Fungsi Kelayakan : Fungsi Kelayakan merupakan fungsi yang memeriksa apakah suatu kandidat yang dipilih dapat memberikan solusi yang layak, yakni kandidat tersebut bersama-sama dengan himpunan solusi yang sudah terbentuk tidak melanggar kendala yang ada.

f) Fungsi Obyektif :Fungsi Obyektif merupakan fungsi yang memaksimumkan atau meminimumkan nilai solusi.

\section{METODE PENELITIAN}

\section{A. Pengumpulan Data dan Informasi}

Teknik pengumpulan data dan informasi yang digunakan dalam penelitian ini adalah dengan melakukan studi literatur dan wawancara. Teknik pengumpulan data yang digunakan untuk membantu proses penelitian diantaranya adalah :

1) Studi Literatur : Melakukan studi literatur untuk mengetahui dan memahami lebih mendalam 
bagaimana Algoritma Greedy dapat melakukan penentuan rute perjalanan terpendek.

2) Wawancara : Melakukan wawancara dengan Kepala Seksi Promosi dan Kerjasama Dinas Kebudayaan dan Pariwisata Provinsi Jawa Timur untuk memperoleh data-data yang diperlukan dalam melakukan penelitian.

3) Pencarian data koordinat: Melakukan pencarian data koordinat lokasi Daya Tarik Wisata dan Hotel melalui Google Map dan jarak antar lokasi yang akan diterapkan pada sistem.

\section{B. Analisa Data dengan Algoritma Greedy}

Data yang telah terkumpul selanjutnya dianalisa melalui tahap analisa data dengan Algoritma Greedy. Adapun beberapa langkah pada tahapan ini, antara lain :

a) Pengelompokan Data : Melakukan pengelompokkan data dari tahapan pengumpulan data yang akan digunakan dalam langkah-langkah perhitungan Algoritma Greedy untuk melakukan pencarian rute perjalanan terpendek.

b) Penerapan Data : Menerapkan data yang siap untuk digunakan untuk perhitungan Algoritma Greedy dan menganalisa hasil perhitungan dengan Algoritma Greedy.

Data koordinat daya tarik wisata dan hotel yang telah diperoleh dari tahapan pengumpulan data dan informasi akan berperan sebagai vertex, sedangkan jarak antar daya tarik wisata dan hotel yang diambil dari Google Map akan berperan sebagai edge. Penyelesaian pada penelitian ini digambarkan dengan graph dan diselesaikan dengan perhitungan Algoritma Greedy yang mana akan menghasilkan total rute perjalanan terpendek antara hotel dengan daya tarik wisata.

Dari hasil-hasil perhitungan data dengan Algoritma Greedy ini dapat diketahui hotel yang mana yang akan memberikan rute perjalanan terpendek dengan daya tarik wisata-wisata yang akan dikunjungi oleh para wisatawan sehingga akan memudahkan wisatawan dalam mendukung keputusan dalam memilih hotel.

Hasil dari tahapan ini adalah data-data yang diperoleh dapat diterapkan pada Algoritma Greedy dan dapat menciptakan solusi masalah penelitian yang akan diimplementasikan pada sistem.

\section{Pembangunan Sistem}

Dalam melakukan pembangunan sistem, sistem akan terlebih dahulu dilakukan perancangan sistem dengan Use Case Diagram, Activity Diagaram dan Perancangan Antarmuka yang menjelaskan fungsifungsi pada sistem dengan Actor calon wisatawan

Untuk perancangan antarmuka akan dibagi menjadi beberapa tahapan yaitu Tahapan Input berada pada tahapan 1-3, Tahapan Proses pada tahapan 4 dan Output pada tahapan 5. Tahapan- tahapan keseluruhan yang ada dalam sistem adalah:

1) Pemilihan Kota Tujuan Wisata : Pemilihan kabupaten/kota tujuan merupakan Input dari pengguna, pengguna akan memilih kota-kota tujuan wisata yang sudah ada di dalam database sistem. Data Kabupaten/kota berjumlah 38 .

2) Pemilihan Daya Tarik Wisata : Pemilihan daya tarik wisata adalah Input kumpulan daya tarik wisata yang ada di dalam setiap kabupaten/kota yang telah dipilih daya tarik yang ada di Jawa Timur total berjumlah kurang lebih 767 wisata.

3) Pemilihan Hotel Menurut Kriteria : Pada tahapan Input ini pengguna dapat menginput jenis hotel sesuai kriteria yang telah ditetapkan dalam sistem, kriteria tersebut adalah Kelas, Harga, dan Review.Semua data mengenai kriteria diambil dari situs pencarian hotel TripAdvisor.com, Booking.com, Hotels.com dan Google Map.

4) Proses Pencarian Hotel Berdasarkan Rute Perjalanan Terpendek Daya Tarik Wisata : Tahapan ini adalah tahapan Proses berupa perhitungan Algoritma Greedy dalam menentukan rute perjalanan terpendek hotel menuju tempat wisata dengan sistem.

5) Proses Pencarian Hotel Berdasarkan Rute Perjalanan Terpendek Daya Tarik Wisata : Tahapan ini adalah output dari sistem yaitu daftar hotel dengan rute perjalanan terpendek dengan daya tarik wisata beserta urutan lokasi perjalanan yang dapat dilalui.

Pembangunan sistem pencarian hotel berdasarkan rute perjalanan terpendek dengan daya tarik wisata menggunakan Algoritma Greedy diimplementasi berupa aplikasi mobile yang menggunakan Java sebagai bahasa pemrograman dan database yang digunakan adalah SQLLite. Sedangkan IDE yang digunakan adalah Eclipse Android Developer Tools (ADT 22.0) dan Google Map.Google Maps merupakan sebuah layanan peta dunia virtual berbasis web yang disediakan oleh Google (Riyanto, 2010)

Hasil dari tahapan pembangunan sistem adalah sebuah aplikasi mobile yang dapat menyelesaikan permasalahan penelitian berdasarkan Algoritma Greedy.

\section{Evaluasi Sistem}

Evaluasi sistem akan dilakukan oleh seorang ahli dalam bidang travelling seperti Traveller, Pengembang Aplikasi Pemetaan dan Pemilik Biro Wisata untuk menguji solusi yang diberikan oleh sistem sehingga para ahli akan memberikan kritik 
serta saran mengenai kinerja sistem selain itu juga akan dilakukan suvey pada sejumlah end-user untuk menjalankan sistem.

\section{HASIL DAN PEMBAHASAN}

\section{A. Hasil Pengumpulan Data dan Informasi}

Pengumpulan Data dan Informasi dilakukan dengan beberapa cara yaitu studi literatur, wawancara dan pencarian data berikut adalah hasil dari tahapan pengumpulan data dan informasi. Hasil dari studi literatur adalah menghasilkan Tinjauan Pustaka yang diambil dari buku referensi, jurnal dan skripsi yang diterbitkan oleh universitas-universitas di Indonesia untuk menyelesaian permasalahan penelitian yaitu tinjauan pustaka mengenai Travelling Salesman Problem, Teori Graph, dan Algoritma Greedy

1) Outline Wawancara : Hasil wawancara adalah berupa outline wawancara yang berisi :

a) Data daftar Kabupaten dan Kota di Jawa Timur.

b) Data daftar Daya Tarik Wisata di Jawa Timur.

c) Data daftar Hotel di Jawa Timur.

d) Kriteria Hotel di Jawa Timur.

e) Fakta pendukung :jarak rute perjalanan terpendek merupakan faktor penting dalam pemilihan hotel dan daya tarik wisata serta penyebaran informasi wisata yang dilakukan pemerintah masih kurang efektif.

2) Koordinat Lokasi : Hasil pencarian data adalah koordinat lokasi hotel dan daya tarik wisata melalui Google Map yang berdasarkan Data Daftar Hotel dan Daya Tarik Wisata dari tahapan wawancara menghasilkan :

a) Koordinat latitude dan longitude Hotel dan Daya Tarik Wisata (vertex).

b) Jarak Antar Hotel dan Daya Tarik Wisata (edge)

\section{B. Hasil Analisa Data dengan Algoritma Greedy}

Data yang diperoleh dari proses pengumpulan data dan informasi selanjutnya diolah dengan menganalisa pengelompokkan data-data yang ada yang sesuai dengan kebutuhan perhitungan Algoritma Greedy. Data-data yang digunakan adalah :

a) Daftar Nama Hotel dan Daya Tarik Wisata sebagai vertex.

b) Nilai edge antar vertex sebagai elemen Himpunan Kandidat (C)

Terdapat beberapa kebiasaan pengguna dalam melakukan perjalanan wisata dan pencarian hotel berdasarkan rute perjalanan terpendek yang dibagi menjadi beberapa skenario menurut vertex awal dan akhirnya yang berbeda seperti berikut :

a) Skenario 1 : Hotel-DTW-Hotel b) Skenario 2 : Home-DTW-Home

c) Skenario $3:$ Home - DTW-Hotel

d) Skenario 4:Hotel-DTW-Home

e) Skenario 5:Hotel-DTW-Another Hotel

Vertex Hotel merupakan Lokasi Hotel yang dipilih user sesuai kriteria.Vertex DTW merupakan Daya Tarik Wisata yang dipilih user sesuai kriteria.Vertex Another Hotel merupakan lokasi Hotel lain terdekat dengan Hotel yang dipilih user sesuai kriteria.Vertex Home merupakan user current location yang diambil secara otomatis dari sistem melalui GPS apabila user ingin melakukan perjalanan dari tempat asalnya. Sedangkan daftar hotel yang dapat dipilih akan difilter berdasarkan kriteria kelas, harga, dan review yang diinput oleh user

Untuk melakukan penerapan perhitungan Algoritma Greedy graph dengan data yang telah diperoleh, Gambar 1 merupakan urutan perjalanan optimal berdasarkan Algoritma Greedy sesuai dengan Skenario 1 berangkat dari titik A kembali ke titik A :

TABEL 1. PEMILIHAN EDGE SKENARIO 1

\begin{tabular}{|c|c|c|c|c|c|}
\hline & $\begin{array}{c}\text { Hotel } \\
\text { Purnama } \\
\text { (A) }\end{array}$ & BNS (B) & $\begin{array}{c}\text { Bumiaji Eco Village } \\
\text { (C) }\end{array}$ & $\begin{array}{c}\text { Coban Talun } \\
\text { (D) }\end{array}$ & $\begin{array}{c}\text { Jatim Park 2 } \\
\text { (E) }\end{array}$ \\
\hline Hotel Purnama (A) & - & 6,22 & 2,15 & 2,68 & 5,29 \\
\hline BNS (B) & 6,22 & - & 4,16 & 8,86 & 1,16 \\
\hline $\begin{array}{c}\text { Bumiaji Eco Villagge } \\
\text { (C) }\end{array}$ & 2,15 & 4,16 & - & 4,71 & 3,36 \\
\hline Coban Talun (D) & 2,68 & 8,86 & 4,71 & - & 7,97 \\
\hline Jatim Park 2 (E) & 5,29 & 1,16 & 3,36 & 7,97 & - \\
\hline
\end{tabular}

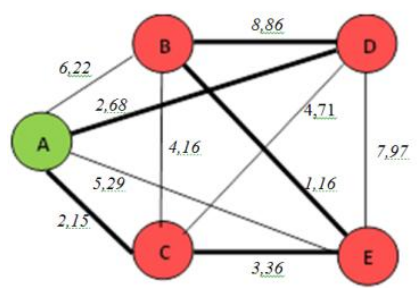

Gambar 1. Graph Perhitungan Greedy Skenario 1

Berdasarkan Tabel diatas rute perjalanan terpendek yang harus ditempuh dari vertex A menuju ke seluruh Daya Tarik Wisata kemudian kembali ke vertex A adalah melalui rute A-C-E-B-D-A.Perhitungan total edge yang telah dioptimasi dengan Algoritma Greedy adalah sebagai berikut :

$\operatorname{Cost}(\mathrm{A}-\mathrm{C})=2,15 \mathrm{~km}$

Cost $(\mathrm{C}-\mathrm{E})=3,36 \mathrm{~km}$

Cost $(\mathrm{E}-\mathrm{B})=1,16 \mathrm{~km}$

Cost $(\mathrm{B}-\mathrm{D})=8,86 \mathrm{~km}$

Cost $(\mathrm{D}-\mathrm{A})=2,68 \mathrm{~km}$

Optimasi :2,15+3,36+1,16+8,86+2,68=18,21 km

Pada Skenario 1 memiliki penyelesaian yang sama dengan Skenario 2 karena vertex awal dan akhir yang sama atau dinamakan dengan Travelling Salesman Problem.Skenario 2 diawali dengan perjalanan awal dari rumah calon 
wisatawan kemudian kembali ke rumah tanpa menginap di hotel setelah mengunjungi tempat wisata.

TABEL 2. PEMILIHAN EDGE SKENARIO 2

\begin{tabular}{|c|c|c|c|c|c|}
\hline & Home (A) & BNS (B) & $\begin{array}{c}\text { Bumiaji Eco Village } \\
\text { (C) }\end{array}$ & $\begin{array}{c}\text { Coban Talun } \\
\text { (D) }\end{array}$ & $\begin{array}{c}\text { Jatim Park 2 } \\
\text { (E) }\end{array}$ \\
\hline Home (A) & 0 & 53.25 & 49.38 & 45.28 & 52.7 \\
\hline BNS (B) & 53.25 & 0 & 4.16 & 8.86 & 1.16 \\
\hline $\begin{array}{c}\text { Bumiaji Eco Village } \\
(\text { (C) }\end{array}$ & 49.38 & 4.16 & 0 & 4.71 & 3.36 \\
\hline Cobann Talun (D) & 45.28 & 8.85 & 4.71 & 0 & 7.97 \\
\hline Jatim Park 2 (E) & 52.7 & 1.16 & 3.36 & 7.97 & 0 \\
\hline
\end{tabular}

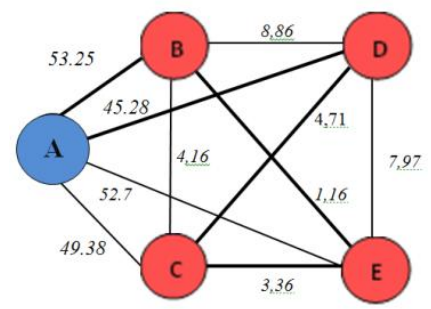

Gambar 2. Solusi Perhitungan Greedy Skenario 2

Optimasi : 45,28+4,71+3,36+1,16+53,25 $=106,76 \mathrm{~km}$ Urutan : A-D-C-E-B-A

Namun, pada Skenario 3, 4, dan 5 akan memiliki penyelesaian Algoritma Greedy yang berbeda karena vertex awal dan akhirnya berbeda yaitu cukup dengan melakukan penyesuaian dengan melakukan pergantian pada vertex dan edge menuju vertex akhir.

\section{TABEL 3. PEMILIHAN EDGE SKENARIO 3}

\begin{tabular}{|c|c|c|c|c|c|}
\hline & Home (A) & BNS (B) & $\begin{array}{c}\text { Bumiaji Eco Village } \\
(\text { C) }\end{array}$ & $\begin{array}{c}\text { Coban Talun } \\
(\mathbb{D})\end{array}$ & $\begin{array}{c}\text { Jatim Park 2 } \\
\text { (E) }\end{array}$ \\
\hline Hotel Purnama (F) & - & $\mathbf{6 . 2 3}$ & $\mathbf{2 . 1 5}$ & 2.68 & 5.3 \\
\hline $\begin{array}{c}\text { BNS (B) } \\
\begin{array}{c}\text { Bumiaji Eeo Village } \\
\text { (C) }\end{array}\end{array}$ & 53.25 & - & 4.16 & 8.86 & 1.16 \\
\hline Coban Talun (D) & 45.38 & 4.16 & - & 4.71 & 3.36 \\
\hline Jatim Park 2 (E) & 52.7 & 1.16 & 3.36 & - & 7.97 \\
\hline
\end{tabular}

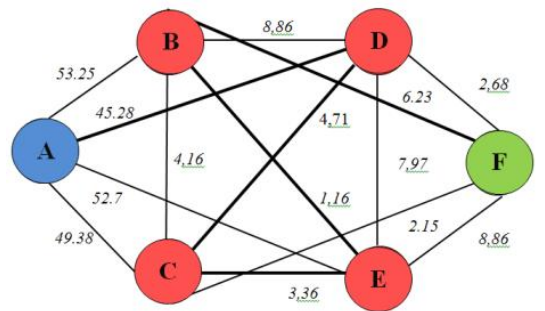

Gambar 3. Solusi Perhitungan Greedy Skenario 3

Optimasi : 45,28+4,71+3,36+1,16+6,23 =60,74 km Urutan : A-D-C-E-B-F

Pada Skenario 3 wisatawan akan melakukan perjalanan berawal dari rumah wisatawn yang dipilihnya kemudian menuju hotel yang dipilih wisatawan setelah mengunjungi seluruh daya tarik wisata.
Tabel 4. PEMILIHAN EDGE SKENARIO 4

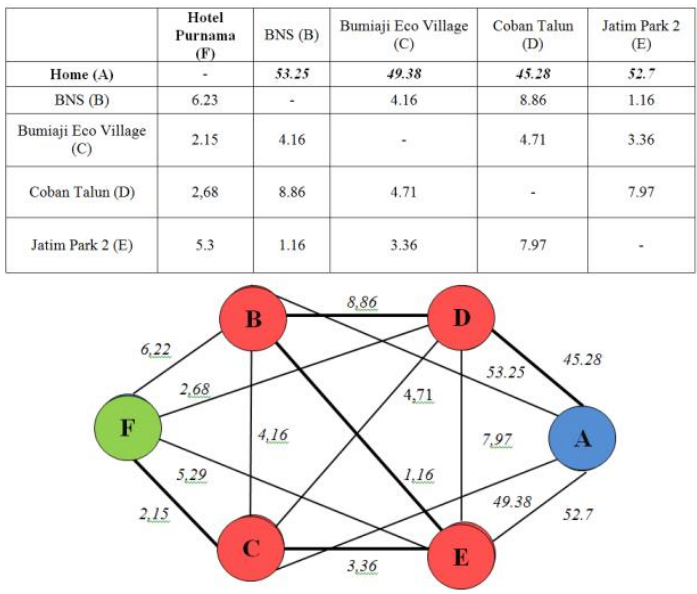

Gambar 4. Solusi Perhitungan Greedy Skenario 4

Optimasi :2,15+3,36+1,16+8,86+45,28 $=60,81 \mathrm{~km}$ Urutan : F-C-E-B-D-A

Pada Skenario 4 wisatawan akan melakukan perjalanan wisata berawal dari hotel yang dipilihnya kemudian menuju rumah wisatawan setelah mengunjungi seluruh daya tarik wisata.

TABEL 5. PEMILIHAN EDGE SKENARIO 5

\begin{tabular}{|c|c|c|c|c|c|}
\hline & $\begin{array}{l}\text { Hotel } \\
\text { Purnama } \\
\text { (A) }\end{array}$ & BNS (B) & $\begin{array}{l}\text { Bumiaji Eco Village } \\
\text { (C) }\end{array}$ & $\begin{array}{l}\text { Coban Talun } \\
\text { (D) }\end{array}$ & $\begin{array}{c}\text { Jatim Park } 2 \\
\text { (E) }\end{array}$ \\
\hline Hotel Batu Suki (F) & . & 4,19 & 0,76 & 4,74 & 3,23 \\
\hline BNS (B) & 6.23 & - & 4.16 & 8.86 & 1.16 \\
\hline $\begin{array}{l}\text { Bumiaji Eco Village } \\
\text { (C) }\end{array}$ & 2.15 & 4.16 & - & 4.71 & 3.36 \\
\hline Coban Talun (D) & 2,68 & 8.86 & 4.71 & - & 7.97 \\
\hline Jatim Park 2 (E) & 5.3 & 1.16 & 3.36 & 7.97 & - \\
\hline
\end{tabular}

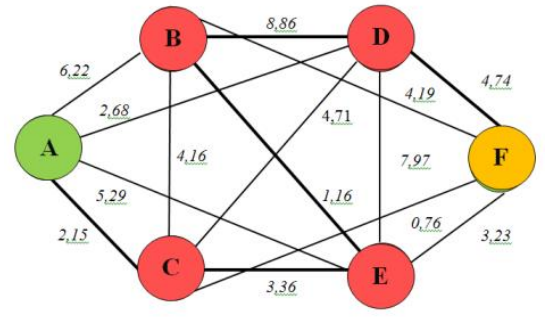

Gambar 5. Solusi Perhitungan Greedy Skenario 5

Optimasi :2,15+3,36+1,16+8,86+4,74=20,28 km Urutan : A-C-E-B-D-F

Pada Skenario 5 wisatawan akan melakukan perjalanan berawal dari hotel yang dipilihnya kemudian menuju hotel lain terdekat mengunjungi seluruh daya tarik wisata.

Dari perhitungan Algoritma Greedy itu dapat dituliskan dalam bahasa pemrograman Java yang nanti akan dapat diterapkan pada aplikasi sebagai berikut : 


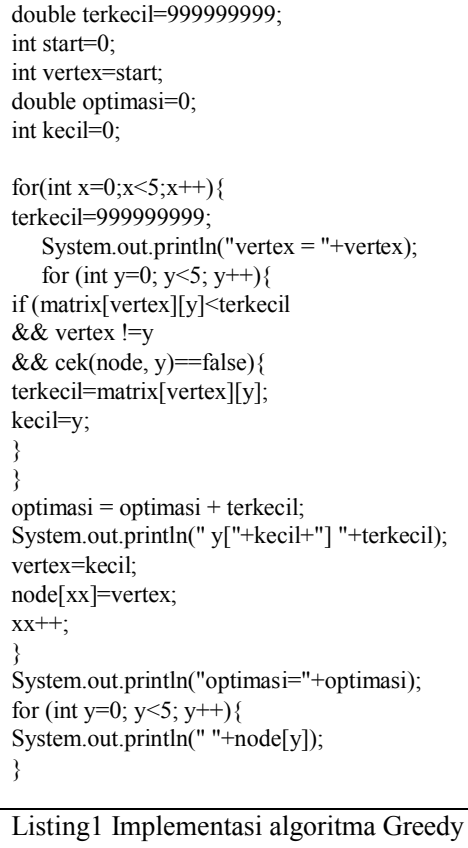

\section{Hasil Pembangunan Sistem}

Dalam tahapan pembangunan sistem adalah mengahasilkan output utama sistem yaitu perhitungan algoritma greedy yang telah ditulis dalam bahasa pemrograman java dan diterapkan pada aplikasi android berbasis mobile mengunakan Google Map APIdengan antarmuka sesuai seperti pada gambar 6 .

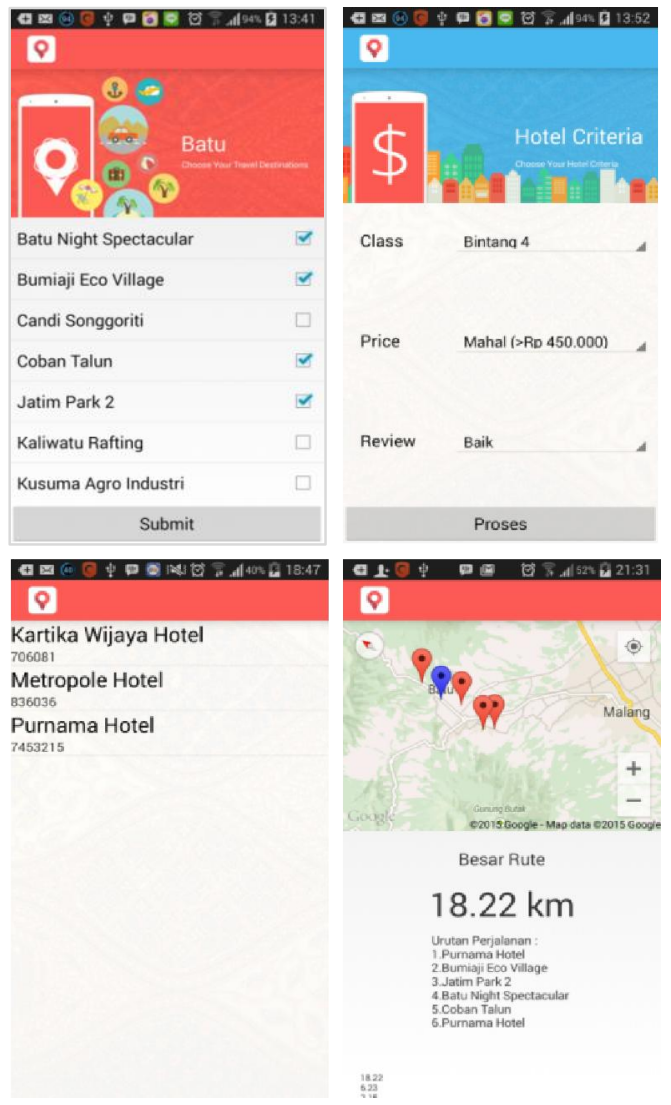

Gambar 6.Tampilan Antarmuka Sistem

\section{Hasil Evaluasi Sistem}

Evaluasi dilakukan dengan mengunakan studi kasus pencarian hotel di kota batu dengan mengunjungi 4 daya tarik wisata di daerah tersebut. Sistem dan para ahli diminta untuk memberikan rekomendasi berdasarkan 5 skenario pola perjalanan yaitu:

a) Dari hotel ke hotel dengan mengunjungi 4 daya tarik wisata.

b) Dari rumah ke rumah dengan mengunjungi 4 daya tarik wisata.

c) Dari rumah ke hotel dengan mengunjungi 4 daya tarik wisata.

d) Dari hotel ke rumah dengan mengunjungi 4 daya tarik wisata.

e) Dari hotel ke hotel yang lain dengan mengunjungi 4 daya tarik wisata.

Para ahli dipilih dari pengusaha biro perjalanan serta traveler ( orang yang sering berwisata).Para ahli memberikan rekomendasi rute serta hotel yang dipilihnya untuk menginap sebelum atau sesudah mengunjungi daya tarik wisata berdasarkan kriteria dan skenario yang telah ditentukan. Setelah itu para ahli diberikan hasil rekomendasi rute dan hotel hasil dari sistem untuk dibandingkan dengan hasil rekomendasi milik para ahli, para ahli diminta pendapatnya tentang perbandingan rute tersebut, apakah setuju dengan rute dan rekomendasi hotel yang dihasil oleh sistem atau tidak.

Hasil dari evaluasi tersebut adalah kesamaan rekomendasi sistem dan ahli adalah 46,7 \%. Ketika rekomendasi antar sistem dan ahli berbeda, Para ahli sebagian besar akan mengikuti rute dan hotel yang direkomendasikan sistem dengan syarat jalur yang diberikan memang lebih pendek dan lebih nyaman untuk dilalui.

Dari hasil masukan dari ahli, ditemukan fakta bahwa kondisi jalan dan tingkat kemacetan dipertimbangkan oleh ahli.Sistem ini hanya melakukan analisa rute berdasarkan jarak mengunakan data dari Google Map API, sehingga terjadi ketidaksesuaian hasil rekomendasi antara ahli dan sistem. Selain itu ahli juga mengakui tidak melakukan perhitungan jarak perjalanan secara teliti, namun hanya berdasarkan perkiraan dan pengalaman.

Evaluasi juga dilakukan pada fitur yang dimiliki oleh sistem dengan mekanisme kuisioner.Berdasarkan kuisioner didapatkan hasil sebagai berikut : tujuan dari sistem dapat $100 \%$ dimengerti oleh para responden, 60\% menyatakan bahwa aplikasi ini memudahkan para wisatawan, $65 \%$ menganggap bahwa sistem cukup mudah untuk dioperasikan, dan tampilan aplikasi dianggap 55\% menarik oleh user. 


\section{KESIMPULAN DAN SARAN}

Berdasarkan hasil evaluasi, dapat disimpulkan bahwa algoritma greedy dapat digunakan untuk memberikan rekomendasi rute perjalanan serta pemilihan hotel untuk menginap sebelum dan atau setelah wisatawan melakukan kunjungan wisata.

Sistem memberikan solusi pemilihan hotel yang tidak sama dengan pilihan ahli karena ahli memiliki pertimbangan tersendiri untuk jalan yang ditempuh. dan tidak menghitung secara rinci jarak antar lokasi, namun para ahli setuju untuk mengunakan hasil rekomendasi rute dan hotel yang dihasilkan oleh sistem.

Hasil evaluasi fitur sistem dapat disimpulkan bahwa sistem memberikan rekomendasi pemilihan hotel dan urutan rute perjalanan wisata secara benar sesuai dengan mempetimbangan jarak perjalanan.Penguna merasa mudah memahami tujuan serta cara pengunaan aplikasi ini, selain itu penguna merasa bahwa aplikasi ini akan membantu wisatawan dalam merencanakan perjalanan wisata terutama dalam pemilihan hotel dan penentuan rute perjalanan.

\section{DAFTAR PUSTAKA}

Efendi, F. S., Pinto, M., \& Tempake, H. S. (2012). Implementasi Algoritma Greedy Untuk Melakukan Graph Coloring: Studi Kasus Peta Propinsi Jawa Timur. Jurnal Informatika vol 4 edisi 2 , 440-448.

Fariza, A., Setyowati, Y., \& Putra, B. J. (2012). Decision Support System of Hotel Selection in Surabaya Based on Android Platform. The 14th Industrial Electronics Seminar 2012 (IES 2012). Surabaya: Electronic Enggineering Polytechnic Institute of Surabaya.

Levitin, A., \& Mukherjee, S. (2007). Introduction to the design \& analysis of algorithms. Vol. 2. Pearson Addison-Wesley.

Lukman, A., AR, R., \& Nurhayati. (2011). Penyelesaian Travelling Salesman Problem dengan Algoritma Greedy. Makassar: Prosiding Konfrensi Nasional Forum Pendidikan Tinggi Teknik Elektro Indonesia (FORTEI) 2011.

Pristanto, Y., Wahyuni, S., \& Handini, Y. D. (2012). Analisis Faktor-faktor Yang Mempengaruhi Keputusan Menginap Pada Hotel Bintang Mulia Jember. Ilmu Administrasi, Fakultas Ilmu Sosial dan Ilmu Politik. Skripsi Universitas Jember.

Riyanto. (2010). Pemrograman Aplikasi Mobile Smartphone dan Tablet PC Berbasis Android. Yogyakarta: Andi. 
[This Page Intentionally Left Blank] 